\title{
The city into the digital: the perception of Oporto
}

\section{A CIDADE NO DIGITAL: A PERCEPÇÃO DO PORTO}

\section{Maria José Faria}

Doutora em Ciências Econômicas e Empresariais, Universidade de Santiago de Compostela.

E-mail: maria_jose_faria@yahoo.com.br

Recebido em 6 de abril de 2018. Aprovado em 9 de maio de 2018.

\section{Abstract}

This article discusses the importance of the increasing use of new technologies for tourist purposes in the imagined construction of the places. The tourism sector, in the context of a globalized world and with its increase, has been the target of marketing strategies currently very cataloged with the new technologies. New digital platforms and websites centered on the city of Oporto, Portugal, and its attractions act as a central element in the search for information and perception of the identity of the place to be visited and appear as an element of competitiveness, giving the city a positive, inspiring and attractive image. This study aimed to evaluate the information and its sources tourists use before visiting Oporto, illustrating how the technologies respond to the requests to visit the city and what is the perception of visitors after the end of their stay. For this purpose, a questionnaire was applied to the tourists visiting Oporto during January 2016, concluding that the new digital platforms and websites contribute to a good image of the city and play an interesting role in the imagined formulation of Oporto.

Keywords: Oporto. Local media. Identity. City branding. Digital platforms.

\section{Resumo}

Este artigo versa a importância da utilização crescente das novas tecnologias para fins turísticos na construção imaginada dos locais. O setor do turismo, no contexto de um mundo globalizado e com seu crescente aumento, tem sido alvo de estratégias de marketing agora muito catalogadas com as novas tecnologias. As novas plataformas digitais e websites, centrados na cidade de Porto, Portugal, e nas suas atrações, agem como elemento central na busca de informação e percepção da identidade do local a visitar e surgem como um elemento de competitividade, atribuindo à cidade uma imagem positiva, inspiradora e atrativa. Este estudo pretendeu avaliar a informação e as fontes de informação que os turistas utilizam antes da visita ao Porto, ilustrando como as tecnologias respondem às solicitações necessárias para visitar a cidade e como resulta a percepção dos visitantes após o término da permanência na cidade. Para tanto, foi aplicado questionário aos turistas que visitaram a cidade durante o mês de janeiro de 2016, do qual se concluiu que as novas plataformas digitais e websites contribuem para uma boa imagem da cidade e têm papel interessante na formulação imaginada da cidade do Porto.

Palavras-chave: Porto. Tecnologias. Turismo. Aplicações móveis. 


\section{Introduction}

Result of a contemporary trend, the city materializes a meaning beyond its name, thereby a name other than the name. In more extensive reference fields, cities are discussed as a product and as a challenging phenomenon of marketing, competing with differentiation and preference and establishing the product-city concept. Thus, the place branding embodies tangible and intangible, formal and symbolic facets that benefit the construction of a narrative about the space. The factors of image, representation and identity are pillars on this process of assigning a brand and they indubitably materialize the personality of the place.

As representations, we can mention the "model cities" as "brand images built by the combined action of local governments along with hegemonic actors with local interests, multilateral agencies and global networks of cities" (SÁNCHEZ, 2001, p. 31). Similarly, but in a more cultural meaning, there are the "literary cities" where culture, in its broadest sense, has been offering an asset to municipal institutions, mainly of touristic interest, inside the construction of a symbolic image.

Likewise, the label of "entertainment city" is developed in line with the spectacularization of urban experience. (VIEIRA, 2008). Therefore, the space is transformed into scenery in which everything is an object of aesthetical and contemplative consumption. Moreover, in an avant-garde perspective, we can remark the notion of "smart city" related to the technological boom of the latest years, in which the city promotion is strongly connected with the digital development, instituting a global city.

\section{Perception of the imagined Oporto}

City communication usually defines its identity. To spread a city's "personality" implies diverse means and forms of communication which can be entitled as perceptible or as symbolic. A relevant discourse that supports the idea of "imagined communities" is referred by Ferrão (2002), who thinks that the metropolis is grounded on everyday experience of several, individual and collective, actors often without explicit interpretation of their own cognitive maps: "the metropolitan experience is not accompanied by a correspondent degree of metropolitan consciousness". The author sustains that there must be a creation of "an innovative geographical scale of territorial identification to construct an imagined community, giving it names, faces, symbols and boundaries, even if invisible" to endorse a new generation of social practices based on multi-presence and sense of belonging. The conception of "imagined communities" presumes the existence of institutions and actors producing a collective sense for the new range of identifications and new interpretative maps, 
by using emotion and symbolic significances because the "imagined community will only be effective if there is a wide sharing of feelings of belonging to the same territory" (Ibid., p. 40).

An interesting process of defining the city is its own means of self-expression, as well as the ones affected by the distinctive achievement of this self-expression: tour guides, websites, corporate city identity, various local media and, in an avant-garde view, mobile applications (apps). As for Oporto, Portugal, it is noticeable how these platforms have helped to create a cultural and attractive city image by answering a required city mapping process in several interactive processes. This interactivity does not exist without intrinsic and extrinsic communication processes, providing the idea that the city is the communication agent. Within a symbiotic process, the city produces a metacommunication, since form and content come together to grant an identity that brands the city as unique and different and likely to be recognized and interpreted. The Ancient, Most Noble, Always Loyal and Unvanquished city of Oporto has gotten the most variegated references in cultural, historical and political feature as a result of its character and localist verve, which is ancestrally connected with people and freedom. This diversity is pointed out by Fernandes (2015) when saying that there are a lot of things to state about Oporto. Specialist on city development, he clarifies that, looking from the outside, "we are a distinct name due to the Port wine, the football and its greatness to the city, without forgetting a third dimension of Humanity Heritage".

This cultural distinction is now fulfilling some historical crisis in which the past was seen like a problem despite the literary movement and the recognized lyricism of Oporto.

Currently, Oporto "is a city that is worth visiting", and is endorsing an image of a "city with character." Considering that the city's touristification is a reality, Oporto has obtained a multi-territorial character which highlights the sentimental relation with the physical and symbolic space, distinguishing Oporto as a unique city (Ibid.).

The discussion of the types of virtual communication and city mapping studies are shown below.

\section{Methodological procedures}

Given the state of the art, it turns out that the tourists visiting Oporto are still unaware of the information available in several different media and apps.

This lack of information made it difficult to assess the impact of such information about Oporto on whom has decided to visit the "Unvanquished city". This had already been examined in a literature review, and this recension verified the inexistence of studies assessing the information and its sources that tourists use before visiting Oporto. 
To cover this gap, we developed a range of appropriate measures to achieve the objectives of our research. However, the lack of studies in this particular issue led to the survey of reliable indicators that could measure the type and sources of information used.

Thus, based on the bibliographic references, we could identify some indicators used in the results of the following studies:

- Diário Económico, no 6117, de 24 de fevereiro de 2015 (Suplemento);

- CARVAlHO, P.; SALAZAR, A; RAMOS, P. Modelo conceptual integrativo de destination branding. Research Days Proceedings of UFP, Porto. 2014.

- Barómetro regional da qualidade: avaliação da satisfação dos turistas (2011);

- CARVALHO, P.; SALAZAR, A; NEVES, J. A imagem percebida e o perfil do turista de um destino turístico cultural: o caso do Alto Douro Vinhateiro, património da humanidade. In: JORNADAS HISPANO-LUSAS DE GESTÃO CIENTÍFICA, 21., fev. 2011, Córdova, Espanha. Actas..., 2011.

- Estudo de avaliação da atratividade dos destinos turísticos de Portugal continental para o mercado interno (2009) - Brandia Central.

The main objective regarding access to information was assessed using a questionnaire exclusively directed to tourists visiting Oporto in January 2016. The interest in preparing the questionnaire resided not only on results verification, but also on looking for validations of the difficulties on accessing information and evaluating the extent type, form and nature of knowledge available/accessed prior to the arrival in Oporto.

To not interfere with the festivities of Christmas and New Year's Day holidays on January 30 and 31, the survey was conducted on the mornings (10 to 12 a.m.) of the last days of January 2016 in different parts of Oporto Old Town, such as the Avenida dos Aliados, Santa Catarina, Cedofeita, Baixa and Ribeira. To this end, the cooperation of the hostels Yes, Tatva and Clip Hotel was required.

As for the tourists and visitors, they were randomly selected to ensure a proportionate and coincident sampling plan. The research was conducted by in-person survey questionnaires, applied personally by researchers. Prior to the data collection questionnaire, a pre-test was carried out to guarantee the intelligibility of the issues/ questions. It was conducted with 10 individuals outside the target audience, which allowed to correct some errors on que questions posteriorly applied to tourists in Oporto.

The questionnaire plan was structured into four parts. The first refers to the characterization of the respondents and the second, to the organization of the stay and the decision to visit Oporto. The third part is related to the type of information and degree 
of satisfaction associated with its use, and the last part assesses the perceptions and motivations to visit and return to Oporto. In the questionnaire, respondents indicated their level of agreement or disagreement to the statements through a Likert scale ranging from 1 (strongly disagree) to 5 (strongly agree).

The first phase of data processing consisted on 207 indicators that constituted the initial database (as many as the survey questions), checked the distribution of values for each indicator and identified the missing data. This phase aimed to fulfill the theoretical assumptions to ensure data normality and homogeneity of variance (SANTOS; RAMOS, 2006, p. 139).

This data preprocessing data used data mining techniques and consisted of two steps: selection and filtering. The selection eliminated the attributes with high percentage of missing data (above $8 \%$ ) considering the maximum sampling error of $5 \%$. Filtering provided the final database.

Data were analyzed with the SPSS Statistics 23 program.

\section{Data Discussion}

\section{Profile}

First, after organizing the information collected, the reading of the data was conducted and indicated the sociocultural characteristics shown in Table 1 and 2.

Table 1. Age of the population

\begin{tabular}{|c|c|c|c|c|c|}
\hline \multicolumn{6}{|c|}{ Age of the population } \\
\hline & & Frequency & Percentage & $\begin{array}{c}\text { Valid } \\
\text { percentage }\end{array}$ & $\begin{array}{l}\text { Cumulative } \\
\text { percentage }\end{array}$ \\
\hline \multirow{8}{*}{ Valid } & $>18$ years & 2 & 3.3 & 3.3 & 3.3 \\
\hline & $18-25$ years & 20 & 33.3 & 33.3 & 36.7 \\
\hline & $25-35$ years & 9 & 15.0 & 15.0 & 51.7 \\
\hline & $35-45$ years & 9 & 15.0 & 15.0 & 66.7 \\
\hline & $45-55$ years & 8 & 13.3 & 13.3 & 80.0 \\
\hline & 55-65 years & 8 & 13.3 & 13.3 & 93.3 \\
\hline & $>65$ years & 4 & 6.7 & 6.7 & 100.0 \\
\hline & Total & 60 & 100.0 & 100.0 & - \\
\hline
\end{tabular}

Source: SPSS.

Tables 1 and 2 show that the population is aged between 18 and 25 years, indicating a relatively young group (33.3\%). Most of the population surveyed was female $(66.7 \%)$ and single (51.7\%). 
Table 2. Sex and marital status

\begin{tabular}{|c|c|c|c|c|c|}
\hline \multicolumn{6}{|c|}{$\operatorname{Sex}$} \\
\hline & & Frequency & Percentage & $\begin{array}{c}\text { Valid } \\
\text { percentage }\end{array}$ & $\begin{array}{l}\text { Cumulative } \\
\text { percentage }\end{array}$ \\
\hline \multirow{3}{*}{ Valid } & Male & 20 & 33.3 & 33.3 & 33.3 \\
\hline & Female & 40 & 66.7 & 66.7 & 100.0 \\
\hline & Total & 60 & 100.0 & 100.0 & - \\
\hline \multicolumn{6}{|c|}{ Marital Status } \\
\hline & & Frequency & Percentage & $\begin{array}{c}\text { Valid } \\
\text { percentage }\end{array}$ & $\begin{array}{l}\text { Cumulative } \\
\text { percentage }\end{array}$ \\
\hline \multirow{5}{*}{ Valid } & Single & 31 & 51.7 & 51.7 & 51.7 \\
\hline & Married & 21 & 35.0 & 35.0 & 86.7 \\
\hline & Divorced & 5 & 8.3 & 8.3 & 95.0 \\
\hline & Widower/Widow & 3 & 5.0 & 5.0 & 100.0 \\
\hline & Total & 60 & 100.0 & 100.0 & - \\
\hline
\end{tabular}

Source: SPSS.

The question "traveling alone or accompanied" denotes that only a quarter of respondents were traveling alone; the other three-quarters were traveling accompanied by friends and/or partners, mostly, followed by family, as shown in Table number 3.

Table 3. Traveling alone or together

\begin{tabular}{c|c|c|c|c|c}
\multicolumn{7}{c}{ Traveling alone/together } \\
\hline \multirow{3}{*}{} & Frequency & Percentage & $\begin{array}{c}\text { Valid } \\
\text { percentage }\end{array}$ & $\begin{array}{c}\text { Cumulative } \\
\text { percentage }\end{array}$ \\
\cline { 2 - 6 } & Alone & 15 & 25.0 & 25.0 & 25.0 \\
\cline { 2 - 6 } & Family & 11 & 18.3 & 18.3 & 43.3 \\
\cline { 2 - 6 } & Boyfriend/Girlfriend & 17 & 28.3 & 28.3 & 71.7 \\
\cline { 2 - 6 } & Friends & 17 & 28.3 & 28.3 & 100.0 \\
\hline
\end{tabular}

Source: SPSS.

Table 4 shows the levels of respondents' education, indicating a major presence of higher education (61.7\%). Only $21.7 \%$ completed secondary education, $13.3 \%$ had other educational levels, as specializations or master's degrees and the minority had basic or primary education $(1.7 \%)$.

According to the cumulative percentage, Table 5 shows that the majority of respondents had full-time $(56.7 \%)$ or part-time (16.7\%) jobs. Such population held an academic degree, were unmarried, from Northern Europe and aged between 18 and 25 
years old. Around a quarter of the sample population was unemployed (26.7\%), which may be explained by these respondents' ongoing studies or their searches for new directions.

Table 4. Level of education

\begin{tabular}{c|c|c|c|c|c}
\multicolumn{7}{|c}{ Level of education } \\
\hline \multirow{4}{*}{} & Frequency & Percentage & Valid percentage & Cumulative percentage \\
\cline { 2 - 6 } & Primary & 1 & 1.7 & 1.7 & 1.7 \\
\cline { 2 - 6 } & Basic & 1 & 1.7 & 1.7 & 3.3 \\
\cline { 2 - 6 } & Secondary & 13 & 21.7 & 21.7 & 25.0 \\
\cline { 2 - 6 } & Higher & 37 & 61.7 & 61.7 & 86.7 \\
\cline { 2 - 6 } & Other & 8 & 13.3 & 13.3 & 100.0 \\
\cline { 2 - 6 } & Total & $\mathbf{6 0}$ & $\mathbf{1 0 0 . 0}$ & $\mathbf{1 0 0 . 0}$ & - \\
\hline
\end{tabular}

Source: SPSS.

Table 5. Professional status

\begin{tabular}{c|c|c|c|c|c}
\multicolumn{7}{|c}{ Professional status } \\
\hline \multirow{3}{*}{} & Frequency & Percentage & $\begin{array}{c}\text { Valid } \\
\text { percentage }\end{array}$ & $\begin{array}{c}\text { Cumulative } \\
\text { percentage }\end{array}$ \\
\cline { 2 - 6 } & Part time & 10 & 16.7 & 16.7 & 16.7 \\
\cline { 2 - 6 } & Full time & 34 & 56.7 & 56.7 & 73.3 \\
\cline { 2 - 6 } & Unemployed & 16 & 26.7 & 26.7 & 100.0 \\
\cline { 2 - 6 } & Total & $\mathbf{6 0}$ & $\mathbf{1 0 0 . 0}$ & $\mathbf{1 0 0 . 0}$ & - \\
\hline
\end{tabular}

Source: SPSS.

As for the respondents' professional status, the analysis indicated that $25 \%$ were students and $12 \%$ were retired. These values cannot answer the previous questions. Values showed that $10 \%$ of respondents were receptionists, $8 \%$ were in administrative jobs, and 7\% were teachers, lawyers and architects (exe quo). The remaining percentages (below 2\%) referred to entrepreneurs, therapists, managers, nurses, department heads, accountants, designers, among others.

Graph 1 evidences that a great part of the respondents' nationality was from countries in the Northern Hemisphere: 15\% of respondents were German, 12\% were Spanish, 10\% were Belgian and English (exe quo), and 8\% were American. The remaining nationalities had a low expression (below 3\%), corresponding to Brazilian, Swiss, Austrian, Chinese, Canadian, Dutch, Australian, Vietnamese and Czechoslovak respondents, among others. 


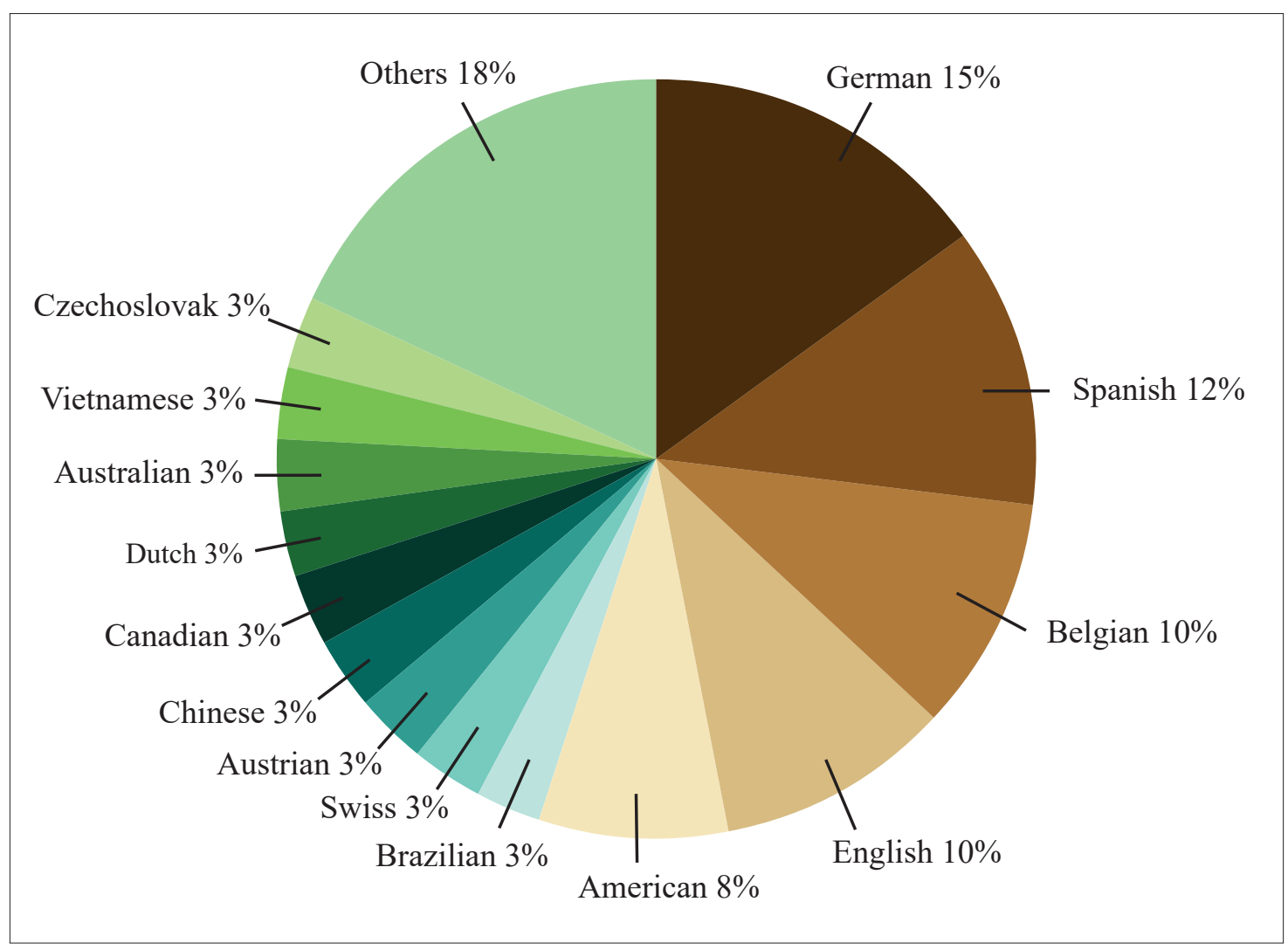

Graph 1. Nationality

\section{Coming to Oporto}

Graph 2 illustrates the means of transport preferably used by tourists on their journey to Oporto. Low-cost flights were the transports most used by tourists, representing $33.3 \%$; this can be justified by the proximity of the city with the airport, and by the low prices charged by airlines, which are very attractive. In addition, regular flights are often used by tourists to access Oporto (28.3\%), which shows that more than $60 \%$ of respondents depended on the airport as a gateway to the "Unvanquished city." The distribution of the remaining means of transport are: $20 \%$ for train, $8 \%$ for car, $7 \%$ for bus, almost $2 \%$ for hitchhiking and the other almost $2 \%$ for other means of transport.

The respondents' length of stay in the city was on average less than a week. Their accommodations were in hostels $(43.3 \%)$, hotels (27\%) residences $(13.8 \%)$ or other places (15.9\%) as shown in Graph 3. 


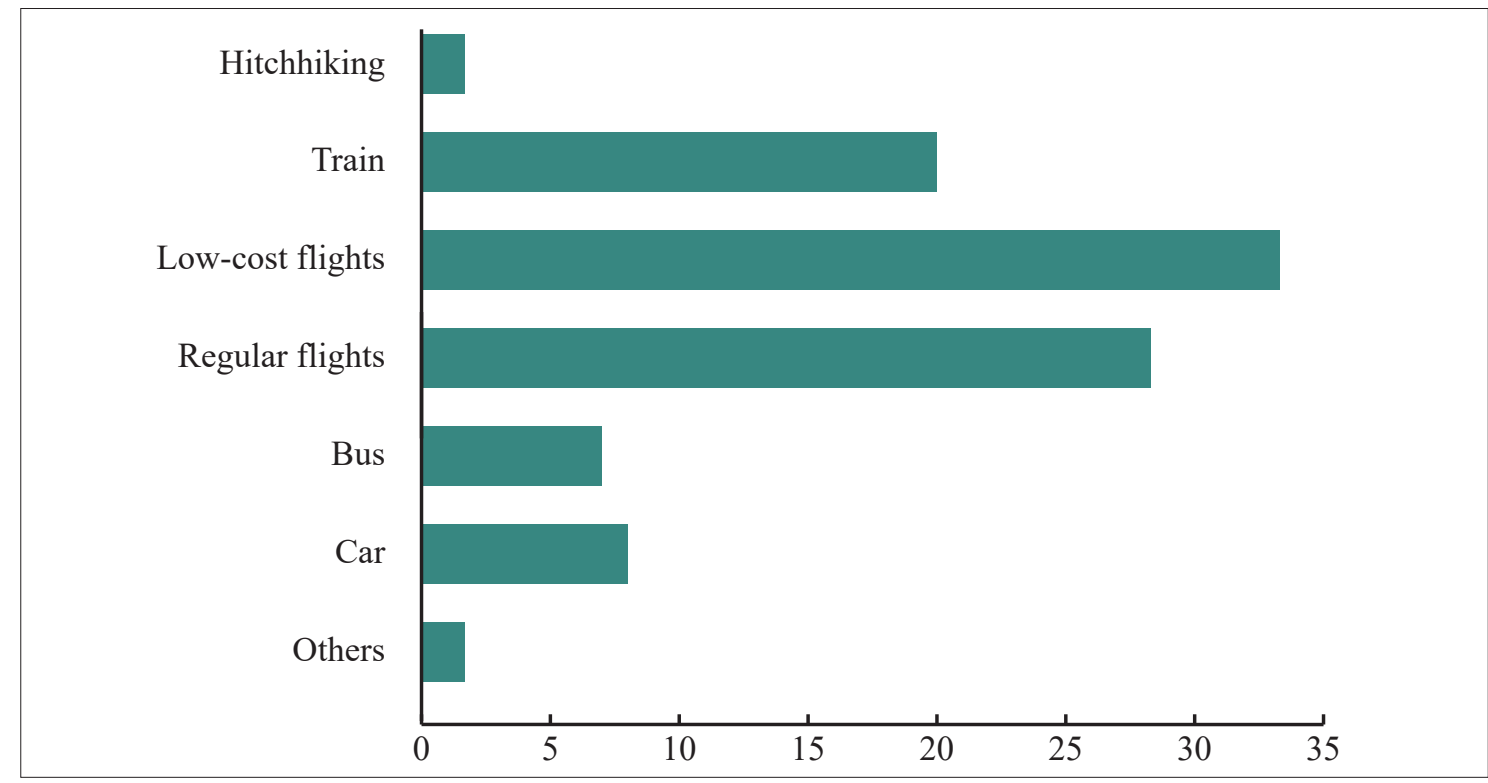

Graph 2. Arrival to Oporto

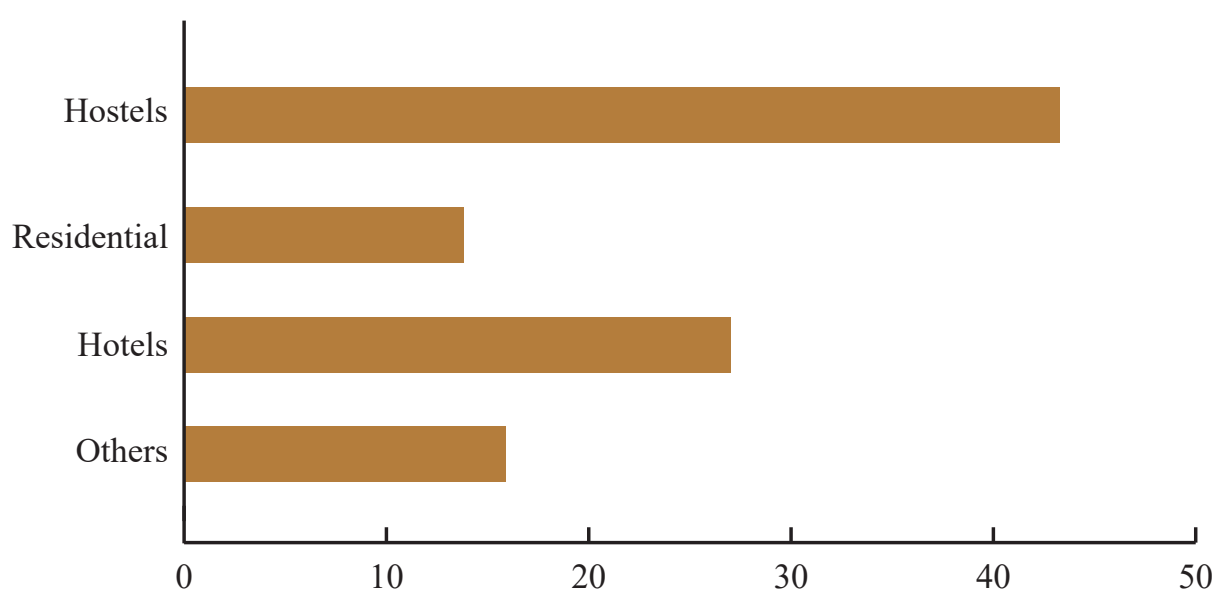

Graph 3. Accommodations in Oporto

\section{Information questionnaire}

The questionnaire applied ascertained the type of information sought about the city. The results indicated that when tourists searched information about Oporto, they focused mostly on hotels, cost of living, gastronomy, nightlife, mobility, environment and safety. Malls and shopping centers were the least searched aspects. 


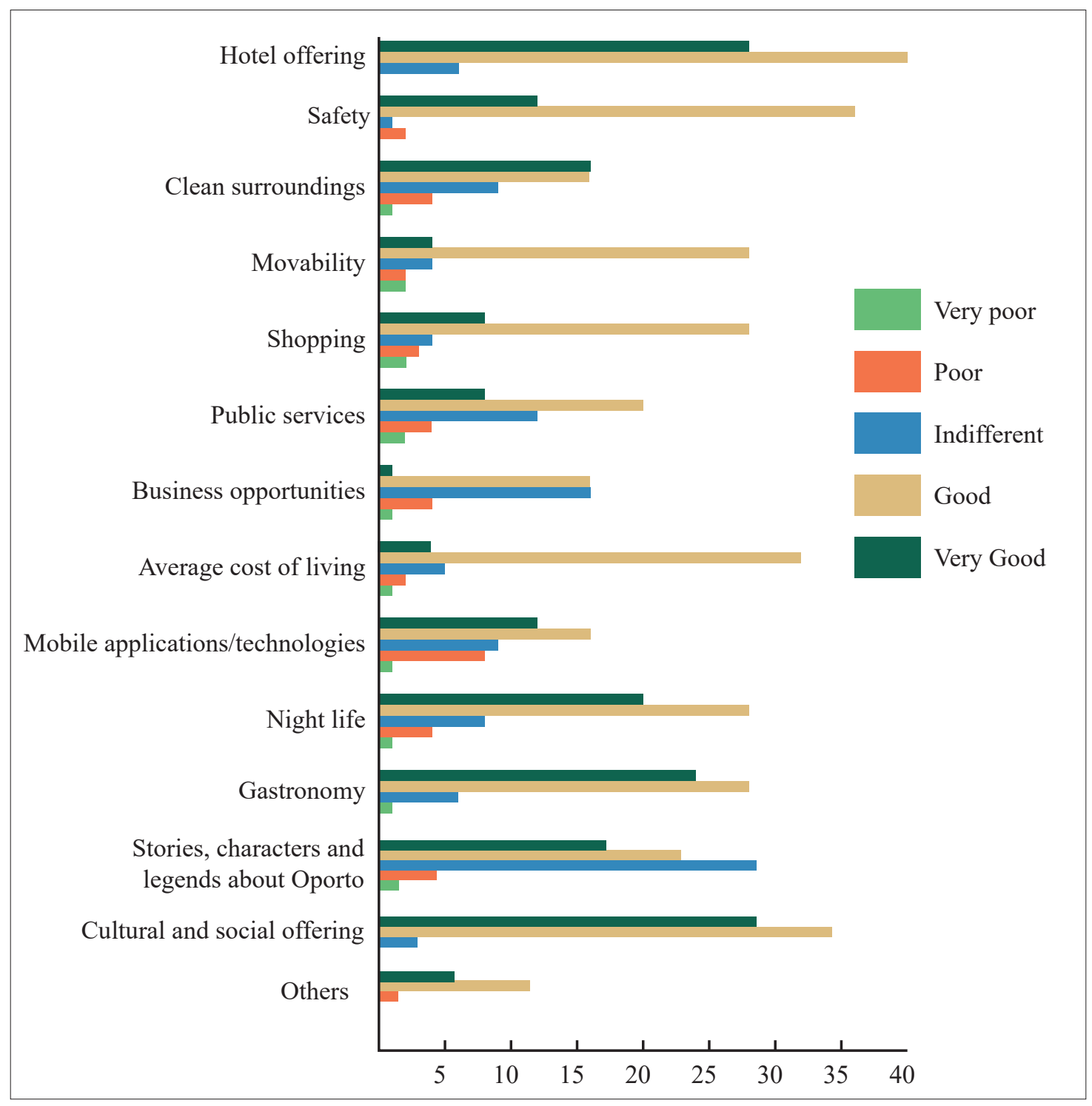

Graph 4. Information searched about Oporto

One of the objectives of this study was to assess how many of the tourists who visited Oporto had or acquired knowledge on legends and stories related to the city. We noted that most of them had no previous information about them nor experienced them during the stay in Oporto. Despite that, the questionnaire showed the tourists' interest on this information $(25 \%)$ and that websites would be a mean of easy access to this type of traditional knowledge $(20 \%)$.

\section{Decision-making/Motivation}

The media, within the traditional or digital venues, is classified as a kind of memory guardian, giving voice to events, cities or communities, removing them from 
obscure areas, where the undeniable power of public visibility creates the conditions to a metaphoric existence shaped by a new potentiality. This research about Oporto - city where its place branding aimed at understanding what kind of information about the city was roughly understood or appreciated by tourists (and the use of mobile applications, thematic sites and social networks due to Oporto) -, could assess what kind of information is explored by visitors or tourists. Mainly, the use of internet to get information about Oporto was the most referred item by those interviewed.

The decision to visit Oporto was formalized based on different types of information (Graph 5). The city reputation, known internationally since the Alto Douro Wine Region was considered an European Cultural Heritage in 2011, scored points in the decision of visiting Oporto (24\%). Similarly, the novelty and curiosity associated with the city were aspects of interest, since many referred to Oporto as a mysterious city. In addition, the allusion to family references or friends who traveled to the city were a great factor for decision-making. Business was another factor of decision for the respondents' visit, among others, with $14 \%$ (exe quo).

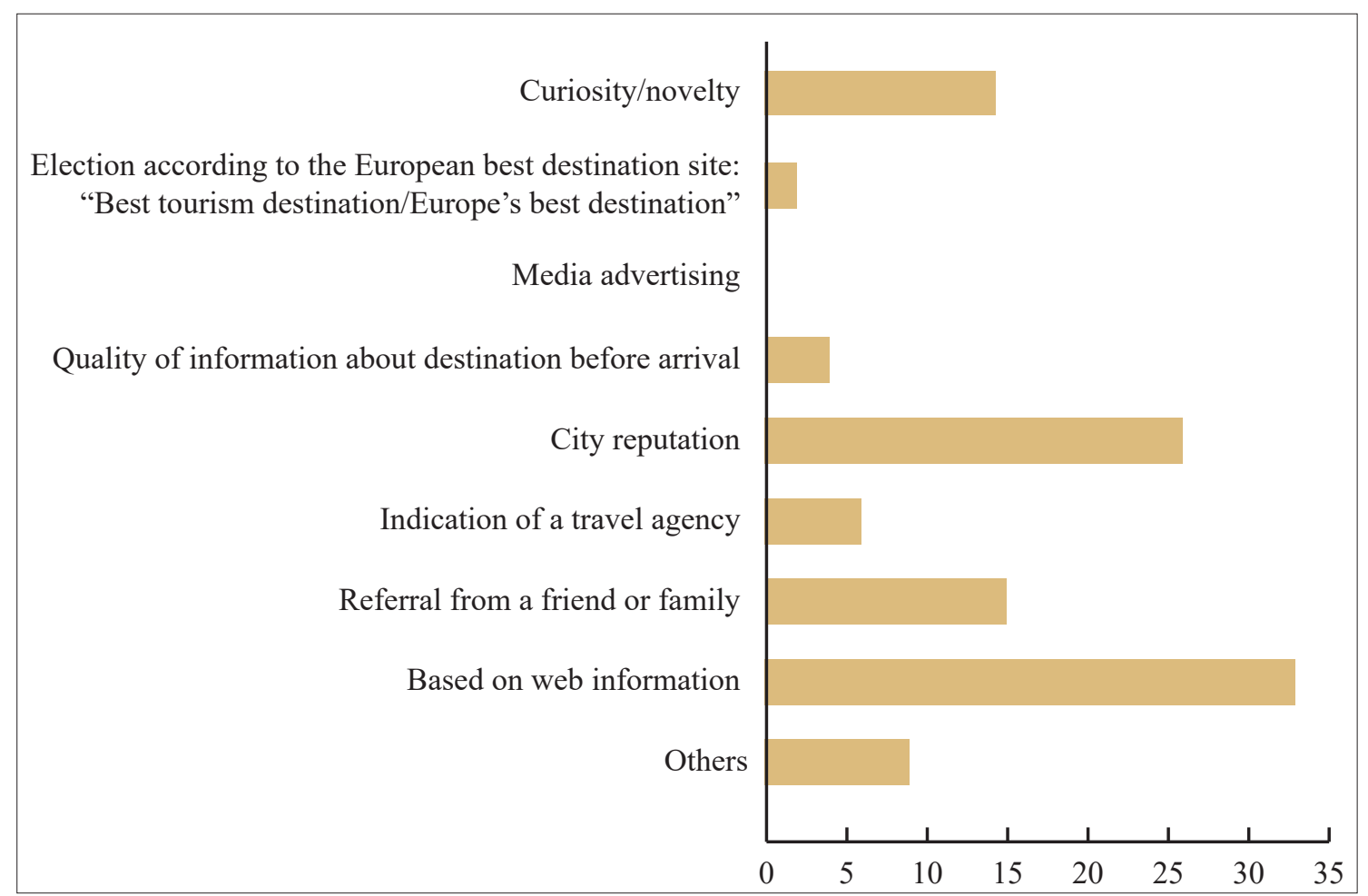

Graph 5. Decision-making in visiting Oporto

As for other means of survey, the Internet was the one most mentioned in searching, virtually visiting and deciding to come to Oporto (30\%). 


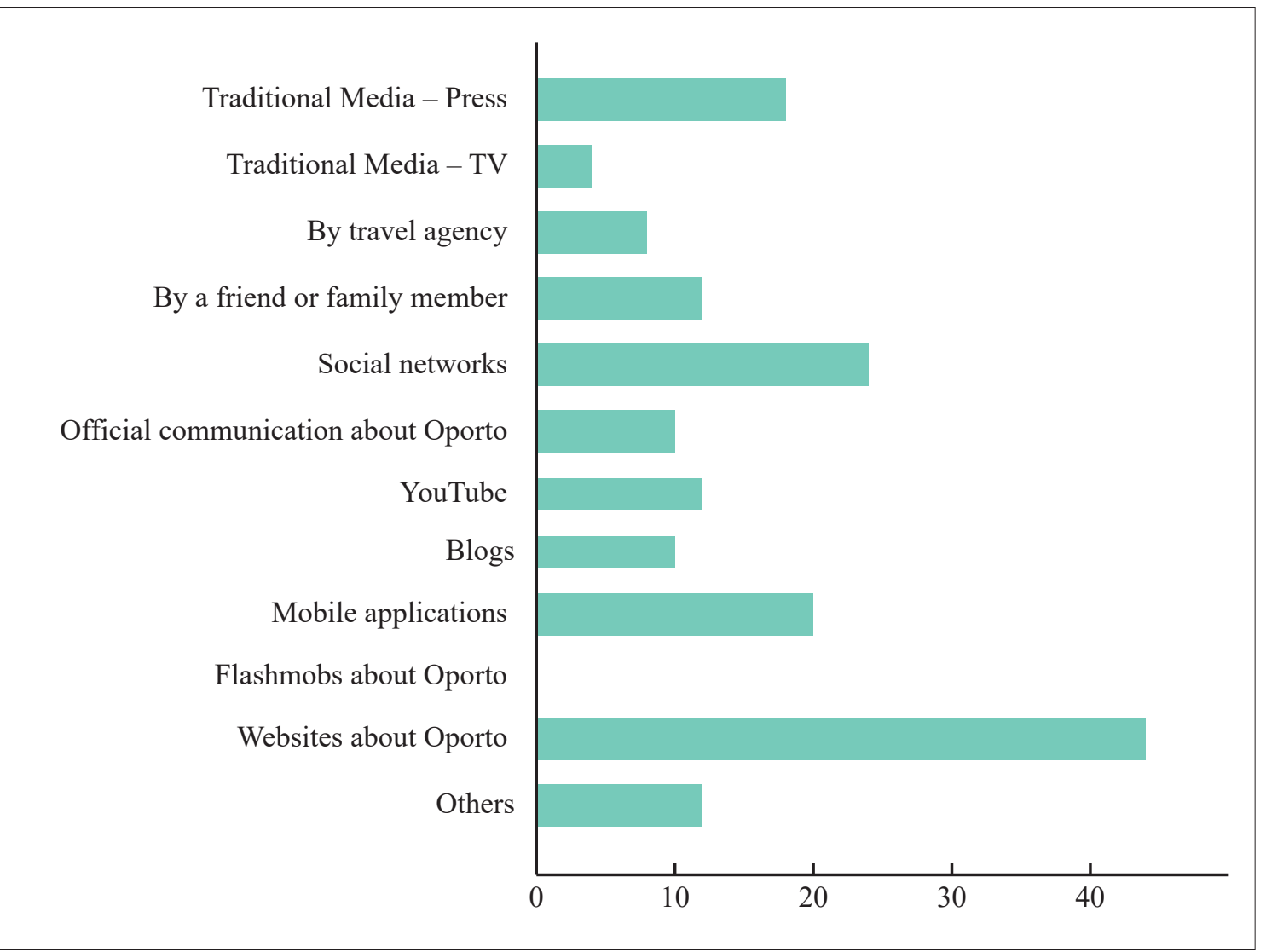

Graph 6. Means of information about Oporto

Most of the information about Oporto was from news websites showing interesting touristic information, such as hotels, monuments to visit, traditional stores and iconic locations. Apps, social networks and traditional media are currently used and privileged by many companies to promote their products and services for consumers as television, travel agencies, youtube, blogs, etc., as shown in Graph 6. On the other hand, magazines were less used to research information about the city.

Since most respondents looked for information about Oporto in multiple sites, being the mobile applications the privileged means, the degree of satisfaction for websites during the visit to the city was high. Despite apps being an excellent mean of information, respondents reported some difficulties in handling and obtaining reliable information. This happens because visitors usually expect to find the most reliable information, which can be found only in the physical visit to the city, in the virtual environment of mobile applications. In addition, online information are not always impartial or true, which may affect some decisions in certain circumstances (Graph 7). 


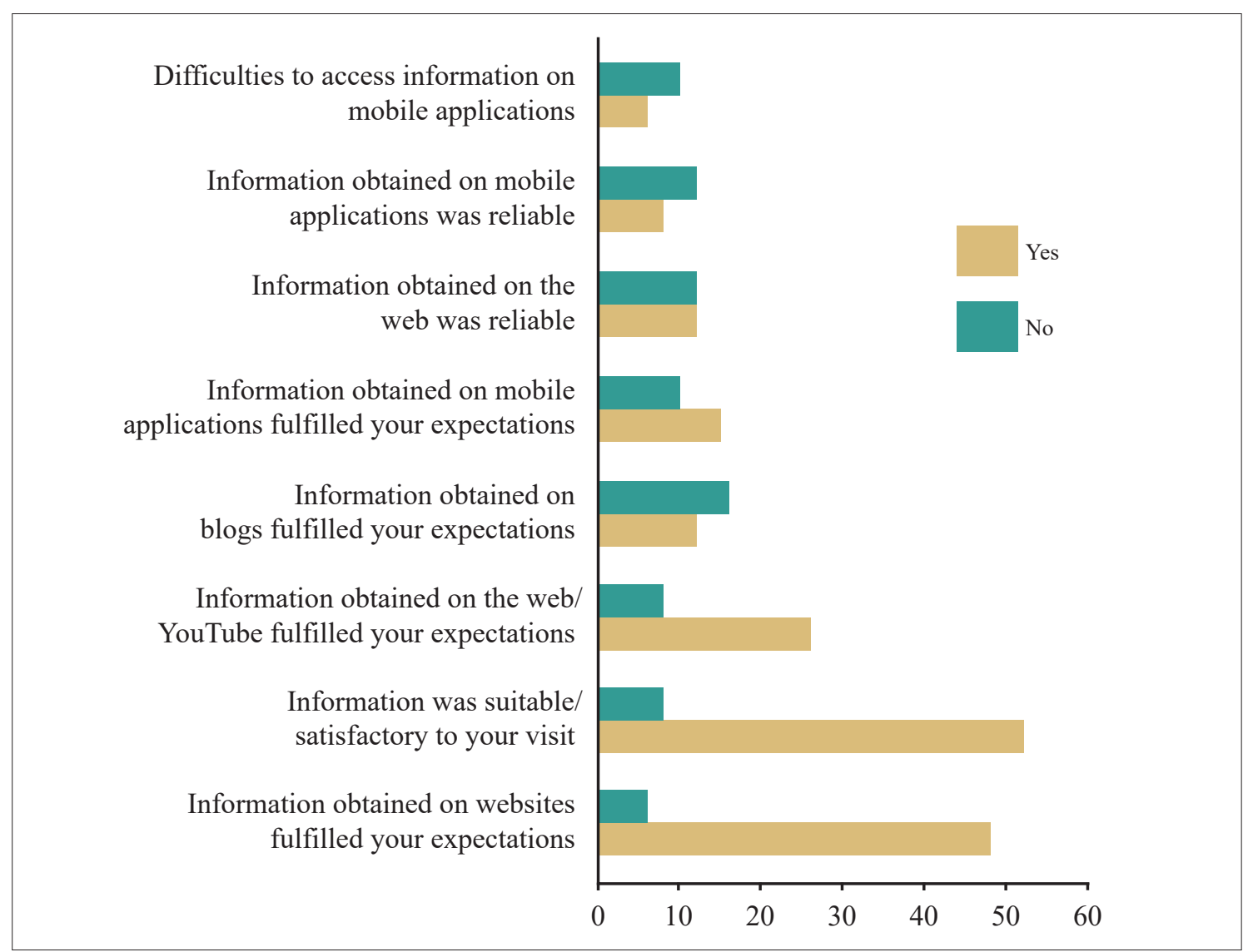

Graph 7. Satisfaction with the information acquired about Oporto

\section{Mobile applications about Oporto}

Websites providing official information about Oporto and apps were the means most used by respondents, followed only by social networks, which evidences the reputation of new technologies related to city branding. Amongst this new tendency, the most visited site was the Visit Porto (Porto Tourism - Official Portal), followed by the mobile applications: "Porto Street Map", "Porto Walking Tours and Maps", "Oporto Tour", "Porto Tour - Official City Pass", “Oporto: Guía de viajes offline”, "Porto Lazer”, "Around Porto" and "MOVEOPORTO - Porto Guide". The use of apps had a satisfaction level below 7\%, which shows the little use of this instrument within this sample of young respondents. The means of information most used by visitors were websites of Oporto (25\%), social networks (14\%), press (12\%), and mobile applications (11\%).

The apps commonly used to find information about Oporto were, according to the respondents, the map of Oporto (14\%), Oporto Tour (11\%), and others (24\%).

Since the majority of respondents were young, their suitability and ability to use mobile applications is notorious; however, the use of multiple apps caused duplication of information, which in many cases, produced some confusion. 


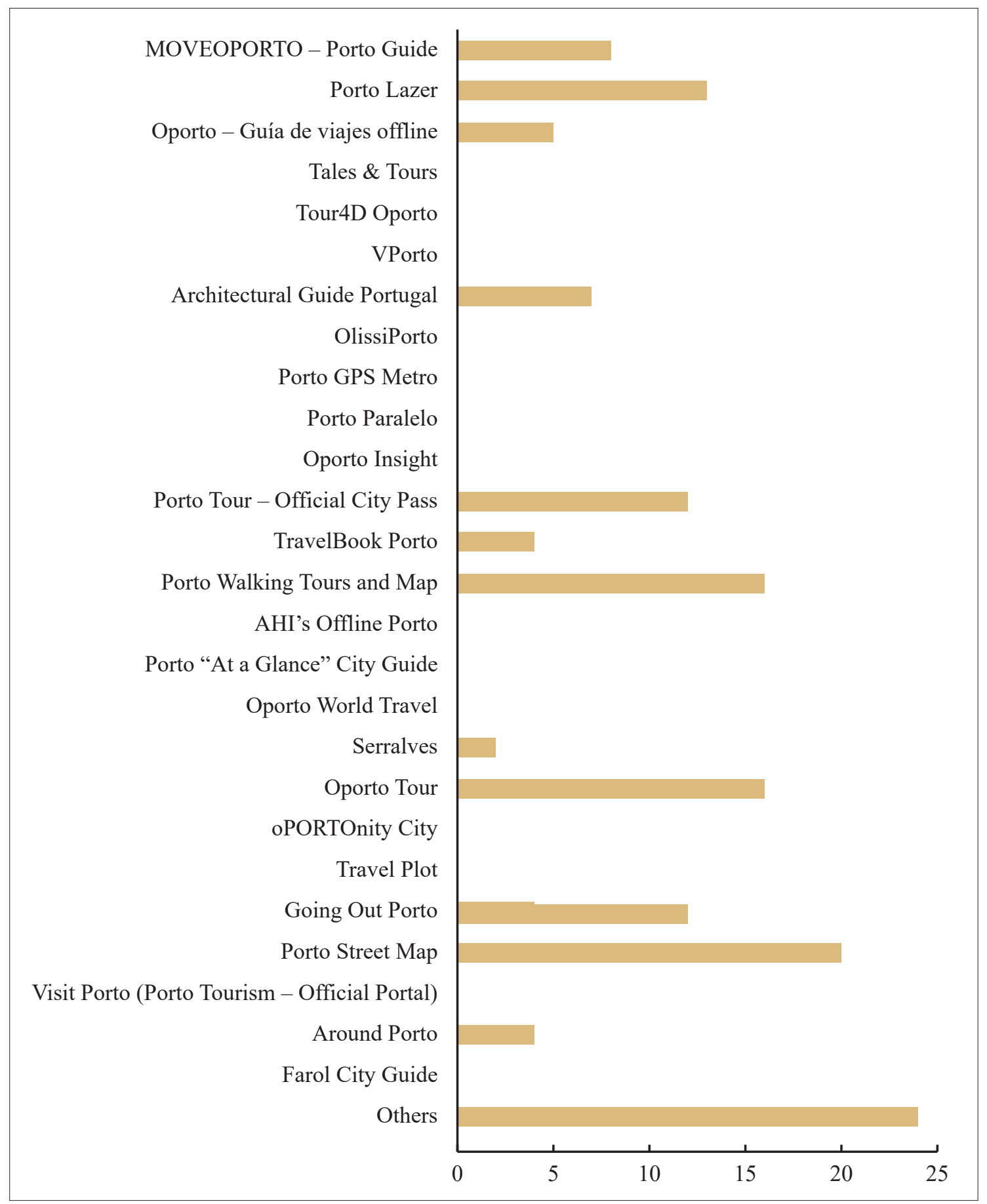

Graph 8. Mobile applications used to find information about Oporto

\section{Conclusions}

Tourists and visitors of Oporto were mostly women, aged between 18 and 25 years, whose countries of origin were Germany, Spain, Belgium and England. The majority of the sample were single and traveling alone, with friends or partners. The sample illustrates 
the respondents' high level of education (higher or secondary). Oporto was the chosen destination for a few days of rest, as a city break, and the means of transport preferred were flights, followed by train trips. Car, bus and hitchhiking were the least preferred choices for traveling. As for the accommodation, visitors preferred to stay overnight in hostels or hotels; however, the choice for residential or other accommodations were not insignificant, but less frequent than the first ones.

Oporto was chosen as a holiday destination mainly because of the information available in the web and the city reputation, which is mainly due to the Historic Center of Oporto (considered world heritage by the United Nations Educational, Scientific and Cultural Organization - UNESCO - since 1996), to the Alto Douro Wine Region (world heritage by UNESCO since 2001) and to the election as Best Tourism Destination in 2014 by the European Best Destinations.

In addition, the promotion of tourism for Oporto is strategic because it adds visibility to a city that seems gray but outstands for its culture, joy and charms of its people, nearness to the sea and for a nature wrapped in a gourmet dish full of pleasures and flavors that only Oporto seems able to offer. These are some perceptional mysteries that makes Oporto a city where tourism is regarded for its fun, stories and adventures. Tourists decide to travel to Oporto and confirm the information available on several websites, the reputation created around a diverse set of humans, cultural and natural elements, the price level in comparison with other European cities, among many other factors that make the city unique.

The respondents of this study stated that they sought information about the city before the arrival. Some of this information is related to the cost of living, shopping, mobility, security, hotel offering, environment, stories, characters and legends, cultural and social aspects, gastronomy, nightlife and affordable technology across town when using mobile applications.

Considering the variety and quantity of apps, the ones most used by tourists were: MOVEOPORTO - Porto Guide, Around Porto, Porto Street Map, Oporto Tour, Port Walking Tours and Map, and Porto Tour - Official City Pass; the websites most used for information were Porto Lazer and Visit Porto (Porto Tourism - Official Portal).

By creating a local reference frame, the media amplifies local visibility and generates an opening to the outside world, not only as a material space but also as a metaphorical one.

Local media and digital media are connected and embody a local reality context, confirming an identity by bequeathing the instruments and means for citizens to learn about societies and communities. Accompanied by new digital platforms, innovative and original information/communication structures, as mobile applications and websites, 
could increase the vibrant atmosphere of Oporto and enlarge the incoming movement of tourists and travel.

\section{References}

ALBUQUERQUE, A. A. O paradigma do mercado no urbanismo: contribuições do marketing para o urbanismo na virada do milênio. 2006. 177 f. Tese (Doutorado em Desenvolvimento Urbano) Universidade Federal de Pernambuco, Recife, 2006.

ANHOLT, S. The Anholt-GMI city brands index: how the world sees the world's cities. Place Branding, New York, v. 2, n. 1, p. 18-31, Jan. 2006.

BEST destinations in Europe. Top places to travel in 2014. European best destinations, 2014. Available from: <https://bit.ly/2klIAOT>. Access on: 24 May 2018.

CAI, L. Cooperative branding for rural destinations. Annals of Tourism Research, Amsterdam, v. 29, n. 3, p. 720-742, July 2002.

CORREIA, J. C. Comunicação e Cidadania: os média e as dinâmicas nas sociedades pluralistas. 2001. Folhas. Tese (Doutorado). Universidade da Beira Interior, Covilhã, 2001.

CRUZ, M. T. Espaço, media e experiência: na era do espaço virtual e do tempo real. Revista comunicação e Sociedade, Lisboa, v. 12, p. 23-27, 2007.

DISCURSO de Miguel Veiga no $33^{\circ}$ Aniversário do 25 de Abril. 3'7”. GCICMP. YouTube. 2007. Available from: <https://bit.ly/2sbLNUG>. Access on: 12 May 2013.

FERNANDES, R. Proceedings of "Porto Conceito". Casa da Cultura de Paranhos. Porto: Gabinete de Estudos do PSD, 2015.

FERRÃO, J. As regiões metropolitanas como comunidades imaginadas: da experiência quotidiana à acção estratégica. In: APOR (Eds.). Porto d'Ideias: a cidade em debate. Porto: Agência para o Desenvolvimento do Porto, 2002. p. 39-42.

GAIO, S.; GOUVEIA, L. B. O branding territorial: uma abordagem mercadológica à cidade. Revista a Obra Nasce, Porto, n. 4, p. 27-36, 2007.

JOLY, M. Introdução à análise da imagem. Campinas: Papirus, 1996.

KAVARATZIS, M. From city marketing to city branding: towards a theoretical framework for developing city brands. Place Branding, New York, v. 1, n. 1, p. 58-73, 2004.

KAVARATZIS, M.; ASWORTH, G. City branding: an effective assertion of identity or a transitory marketing trick? Tijdschrift Voor Economische en Sociale Geografie, Hoboken, v. 96, n. 5, p. 506-514, Nov. 2005.

NOVO logótipo da Câmara Municipal do Porto. Logotipo PT, Lisboa, 1 Oct. 2014. Available from: <https:// bit.ly/2kmsKnb>. Access on: 24 May 2018. 
MOREIRA, J. R.; SILVA, M. J. Marketing das cidades estudo da identidade: o caso da cidade da Covilhã. Revista Conocimiento, Innovación y Emprendedores: Camino al Futuro, Rioja, número, p. 2114-2127, 2007.

PORTO DOS MUSEUS. Homepage do site Porto dos Museus. Porto dos Museus, [S.1.], 2017. Available from: <https://bit.ly/2KPCr8S $>$. Access on: 24 May 2018.

SÁNCHEZ, F. A reinvenção das cidades na virada de século: agentes, estratégias e escalas de ação política. Revista Sociologia Política, Curitiba, n. 16, p. 31-49, June 2001. Available from: <https://bit. ly/2J1rP9G>. Access on: 27 June 2017.

SOUSA, J. Do que falamos quando falamos de Porto? História, mito e identidade de uma cidade genuína e de carácter. Porto Conteito: Porto, 2015. Available from: $<$ https://bit.ly/2s4lVuC $>$. Access on: 24 May 2018.

VIEIRA, C. Cidades literárias e cidades digitais: a página literária do Porto. In: CONGRESS OF THE AMERICAS, II, 2008, Cidade do México. Anais... Cidade do México, ICA, 2008. p. 00.

VISIT PORTO TRAVEL. (@visitporto). Visit Porto. Twitter, [S.1.], 2010. Available from: <https://bit. ly/2IL4YvJ>. Access on: 26 Oct. 2015. 